УДК 327

\title{
NOWE WEKTORY POLITYKI ZAGRANICZNEJ POLSKI PO WYBORACH 2015 R. I ICH KONSEKWENCJE DLA RELACJI POLSKA-UKRAINA
}

\author{
Maciej Mróz \\ Instytut Studiów Międzynarodowych, Uniwersytet Wroctawski, \\ ul. Koszarowa, 3, Wroctaw, Polska, 51-149
}

\begin{abstract}
Zapowiedziane przez obóz zwycięskiej po wyborach 2015 r. prawicy w Polsce zmiany objęły także politykę zagraniczną, zakładały one m.in. zwiększenie podmiotowej roli Polski w Unii Europejskiej, porzucenie nadmiernego ulegania sugestiom płynącym z twardego jądra Unii - Berlina i Paryża, powrót do idei międzymorza oraz uczynienie z Wielkiej Brytanii czołowego partnera Warszawy w Europie. Nowa polityka zagraniczna Polski nie pozostała bez wpływu na poziom relacji bilateralnych z Ukraina. Dotychczasowy model relacji polsko-ukraińskich opartych na tzw. strategicznym partnerstwie dobiega końca, a to oznacza ostateczne pogrzebanie przez Warszawę idei ULB i przejście Polski do realizacji wizji quasi-mocarstwowości i międzymorza $\mathrm{z}$ udziałem państw uczestników spotkania bukaresztańskiego, a zatem bez Ukrainy. Z drugiej strony w obliczu słabnącej pozycji Polski w UE, będzie malało jej zainteresowanie Ukrainą, ponadto kilkanaście ostatnich miesięcy pokazuje, iż Kijów nie jest zanadto przekonany do koncepcji większego zaangażowania Warszawy w rozwiązanie konfliktu ukraińsko-rosyjskiego i nie dostrzega potrzeby rozszerzenia formatu normandzkiego o inne kraje, w tym Polskę.
\end{abstract}

Slowa kluczowe: Polska; Ukraina; Unia Europejska; NATO; Stany Zjednoczone Ameryki; Federacja Rosyjska; międzymorze.

W klasycznym modelu państwa polityka zagraniczna służy, wedle różnych definicji, przede wszystkim do maksymalizacji zysków wynikających z potencjału kraju i otoczenia międzynarodowego, a więc aktualnego układu sił na świecie. Jest ona postrzegana zazwyczaj jako proces o charakterze zmiennym i dynamicznym, zjawisko społeczne, niezbędne państwu do istnienia i rozwoju. Takie właśnie rozumienie polityki zagranicznej, zakładającej maksymalizację sytuacji korzystnych, przy jednoczesnej minimalizacji niekorzystnych, najczęściej dominuje w literaturze politologicznej [6, s. 122].

Polityka zagraniczna - według politologów - to także zorganizowany i skierowany na zewnątrz wysiłek państwa, podporządkowany osiąganiu jego żywotnych interesów, który wyraża się w kształtowaniu jego zewnętrznego otoczenia [8, s. 76], ale także proces racjonalnego myślenia decydentów, warunkowany przez ich sposób odczytania interesu narodowego, motywacje szczegółowe, analizę sytuacji międzynarodowej czy też bilansowaną ocenę własnych możliwości [7].

W wyniku wygranych wyborów w październiku 2015 r. do władzy w Polsce doszła koalicja partii prawicowych pod przywództwem Prawa i Sprawiedliwości, zapowiadająca tzw. dobra zmianę, także w polityce zagranicznej, polegającą m.in. na zwiększeniu podmiotowej roli Polski w Unii Europejskiej i porzuceniu nadmiernego zdaniem polityków prawicowych - uleganiu sugestiom płynącym z Berlina i Paryża,

(C) Mróz Maciej, 2016 
przy jednoczesnym uczynieniu z Wielkiej Brytanii czołowego partnera Warszawy w Europie. Rodzi się zatem w sposób nieuchronny pytanie: czy od czasu objęcia władzy w 2015 r. przez partie prawicowe pod egidą Prawa i Sprawiedliwości nastąił jakościowy zwrot w polityce zagranicznej Polski i jakie były jego konsekwencje dla relacji bilateralnych z Ukrainą?

Wśród zasadniczych wyróżników nowej polityki zagranicznej rządu wypada na pierwszym miejscu wymienić:

1. Przesłanki ideowe i polityczne reorientacji polityki zagranicznej rządu premier Beaty Szydło wynikające $\mathrm{z}$ przekonania o postępującej dezintegracji Unii Europejskiej, wasalnej - zdaniem polityków prawicowych na czele z Jarosławem Kaczyńskim - roli Polski wobec Berlina i Paryża [1, s. 2]. PiS z partii nazywanej na Zachodzie konserwatywną stał się nacjonalistyczno-populistyczną, co wydatnie wpłynęło na pogorszenie wizerunku Polski na arenie międzynarodowej. Wraz z objęciem władzy przez prawice nastąpiło swoiste wypowiedzenie przez nową ekipę rządową konsensusu, zawartego po przemianach ustrojowych w sprawie polityki zagranicznej Polski i zasadniczych założeń polskiej racji stanu, a sama polityka zagraniczna RP stała się parasolem ochronnym dla dobrej zmiany, co w konsekwencji oznaczało prymat polityki wewnętrznej nad międzynarodową. Symbolem odejścia od dotychczasowych pryncypiów było m.in. wystąpienie 20 maja 2016 r. premier Szydło w sejmie przeciwko Komisji Europejskiej i bezprecedensowy atak na opozycję, czy też niecodzienna uchwała $\mathrm{w}$ sprawie ochrony suwerenności. $\mathrm{Z}$ drugiej strony można było zaobserwować tzw. dyplomacje publicystyczna szefa MSZ Witolda Waszczykowskiego (kontrast na tle wiceministra Szymańskiego), notabene zawodowego dyplomaty, najgorzej obok szefa resortu rolnictwa ocenianego ministra w rządzie PiS, co w sposób naturalny wiąże się z następnym problemem posiadającym poważny wpływ na politykę zagraniczną Polski, w tym także na relacje z Ukrainą. Jest nim niewatpliwie:

2. Pozakonstytucyjny - obok rządu, prezydenta i szefa dyplomacji - ośrodek podejmowania zasadniczych decyzji $w$ średnio i długofalowym wymiarze $w$ odniesieniu do polityki zagranicznej RP, mający charakter fenomenu jednorazowego, niemającego analogii we współczesnej Europie, chociaż do pewnego stopnia, zgodny z polską tradycją - rządy pomajowe 1926 .

Kolejna kwestia w odniesieniu do polityki zagranicznej państwa to demonstracyjne:

3. Odejście ekipy rządowej od ścisłej współpracy z tzw. twardym jądrem UE Niemcami i Francją, na rzecz zacieśnienia relacji z Wielką Brytanią, Węgrami i Grupą Wyszehradzką [4]. Z perspektywy ostatnich miesięcy można postawić diagnozę, iż w efekcie działań polskiej dyplomacji nastąpiła postępująca samoizolacja i marginalizacja pozycji Polski w UE, poprzez m.in odrzucenie lansowanej przez poprzedni rząd koncepcji, iż czym silniejsza Polska w UE, tym większa siła oddziaływania polityki zagranicznej, np. w stosunku do Ukrainy (Partnerstwo Wschodnie) czy też w relacjach z Rosją (Realpolitik rządu Donalda Tuska). Szczególnie niepokojąco brzmią dla Polski płynące z Brukseli sygnały o możliwości in spe powołania tzw. nowej Unii bez Polski, w oparciu o kraje strefy euro oraz 
otwarte na wspólne rozwiązywanie problemu uchodźców, od którego rząd premier Szydło wyraźnie się dystansuje.

Najbardziej charakterystyczną cechą świadczącą o prymacie polityki wewnętrznej nad zagraniczną w wydaniu PiS jest ponad wszelką wątpliwość:

4. Konflikt wokół Trybunału Konstytucyjnego w Polsce i jego międzynarodowe implikacje, także w odniesieniu do kwestii realizacji polityki zagranicznej Polski wobec wiodących partnerów europejskich oraz Stanów Zjednoczonych. Na gruncie unijnym nowa polityka zagraniczna Polski pod rządami PiS to postrzeganie projektu europejskiego jako schyłkowego [1, s. 9], nieprofesjonalne i obraźliwe m.in. ataki ad personam członków polskich władz pod adresem polityków europejskich, a zwłaszcza sprawa opinii Europejskiej Komisji na rzecz Demokracji przez Prawo, potocznie zwaną Komisją Wenecką Rady Europy, a także w związku z procedurą unijną wizyty w Warszawie w kwietniu 2016 r. Jeana-Claude'a Junckera i wiceszefa Komisji Europejskiej Fransa Timmermansa. Kulminacją sporu z Komisją Europejską, w związku z oskarżeniami Brukseli o łamanie zasad demokracji i państwa prawa w Polsce, była przyjęta znaczną większością głosów 13 kwietnia rezolucja Parlamentu Europejskiego w sprawie demokracji w Polsce, a wreszcie negatywna opinia Komisji Europejskiej o stanie praworządności z 1 czerwca 2016 r.

Z kolei w relacjach z USA nowa polityka zagraniczna Polski pod rządami prawicy przyniosła ze sobą list senatorów amerykańskich w sprawie kondycji demokracji w Polsce i wykraczająca poza standardy dyplomatyczne odpowiedź premiera RP. Ponadto już w połowie lutego 2016 r. sekretarz stanu John Kerry nawiązywał publicznie do kryzysu w Polsce podczas wizyty ministra Waszczykowskiego w Waszyngtonie. Za kulisami wielkiej dyplomacji Amerykanie usiłowali w sposób pośredni wpływać na polskie władze w kierunku wyciszenia sporu wokół Trybunału Konstytucyjnego [5, s. 7]. Na początku marca w siedzibie PiS na Nowogrodzkiej doszło do spotkania prezesa Kaczyńskiego z ambasadorem USA Paulem W. Jonesem.

Cechą specyficzną amerykańskiej dyplomacji w odróżnieniu od tradycji europejskiej, przywiązującej wagę do kwestii protokołu i języka, jest stawianie spraw w sposób bardzo bezpośredni, w odróżnieniu np. od brukselskiej poprawności politycznej i dyplomatycznej niefrasobliwości, oraz czerpanie informacji na temat sytuacji wewnętrznej kraju-partnera z bardzo pewnych źródeł. Spotkanie miało charakter nietypowy, ponieważ prezes Kaczyński jest znany z tego, iż unika rozmów z dyplomatami. Wcześniej w Warszawie były ambasador Daniel Fried, koordynator Departamentu Stanu ds. sankcji, a po nim Victoria Nuland, prawa ręka sekretarza Kerry'ego ds. Europy i Azji naciskali na polski rząd w sprawie Trybunału Konstytucyjnego i opinii Komisji Weneckiej. Podobny charakter miały rozmowy przeprowadzone 21 marca 2016 r. podczas spotkania prezydenta Andrzeja Dudy w Krakowie z 5 senatorami z Komisji Wywiadu, poprzedzone bardzo ostrym artykułem w opiniotwórczym «New York Timesie», gdzie znalazło się stwierdzenie, że - Polacy nie rozumieja podstaw demokracji.

Od listu senatorów, w tym bardzo dotychczas życzliwego Polsce Johna McCaina, USA zmienia politykę wobec rządu PiS z twardej ad extra na bardziej miękką ad intra, przenosząc jej ciężar $\mathrm{z}$ forum publicznego w zacisze gabinetów. Jednak pomimo 
głosów płynących z kręów opozycji w kwestii spodziewanej odmowy strony amerykańskiej dotyczącej spotkania na najwyższym szczeblu, doszło z inicjatywy prezydenta USA do kurtuazyjnej rozmowy z polskim przywódcą podczas szczytu nuklearnego na przełomie marca i kwietnia 2016 r. Nie można jednak wykluczyć, iż powodem wymiany zdań była chęć zademonstrowania przez prezydenta Obamę obaw Stanów Zjednoczonych związanych z konfliktem wokół Trybunału Konstytucyjnego. Zapewne inicjatywa amerykańska w pierwszym rzędzie została spowodowana pojednawczymi gestami ze strony obozu rządzącego, czego przejawem był apel prezesa Kaczyńskiego o wyciszenie sporu politycznego w Polsce i mające miejsce w jego wyniku 31 marca 2016 roku spotkanie z opozycją w sejmie, a także koncyliacyjne wypowiedzi prezydenta Dudy w trakcie konferencji $\mathrm{z}$ mediami w Waszyngtonie.

Wydaje się, iż w najbliższej przyszłości przez wzgląd na konflikt wokół Trybunału Konstytucyjnego oraz brak efektów związanych z delikatnymi naciskami amerykańskiej administracji w sprawie przestrzegania zasad demokracji w Polsce, nie należy oczekiwać zmiany klimatu w relacjach bilateralnych. Niewątpliwie także Waszyngton nie traktuje polskiego prezydenta jako samodzielnego, a co najważniejsze - decyzyjnego polityka, mając pełną świadomość tego, gdzie znajduje się ośrodek podejmowania decyzji w Polsce. Przebieg wizyty prezydenta Dudy w USA, a zwłaszcza program spotkań, poza małym, jednak wyłącznie protokolarnokurtuazyjnym wyjątkiem, nieobejmujący spotkań z wpływowymi politykami na Kapitolu świadczy pośrednio o pogarszającym się obrazie Polski w Stanach Zjednoczonych. $Z$ drugiej jednak strony informacja o skierowaniu do Europy ciężkiej amerykańskiej brygady pancernej, być może do Polski, i symboliczne zainicjowanie 13 maja 2016 r. budowy w Redzikowie elementów amerykańskiej tarczy antyrakietowej oznacza odejście USA od zapoczątkowanej po upadku ZSRR drastycznej redukcji obecności wojskowej Stanów Zjednoczonych na Starym Kontynencie. Postępujące ochłodzenie relacji polsko-amerykańskich znalazło także wyraz podczas wizyty premier Szydło w USA w związku z podpisaniem deklaracji klimatycznej w siedzibie ONZ w Nowym Jorku, przy okazji którego nie doszło do żadnego spotkania z przedstawicielami administracji amerykańskiej. Najważniejsze znaczenie w całokształcie relacji polsko-amerykańskich posiadają dla Warszawy ex definitione kwestie bezpieczeństwa, dlatego też obserwatorzy zwracają baczną uwagę na:

5. Relacje polsko-amerykańskie w przededniu szczytu NATO w Warszawie.

Do annałów dyplomacji przejdzie zapewne fakt, iż polski szef MON poucza największego sojusznika i gwaranta niepodległości - Stany Zjednoczone w kwestii demokracji na cztery miesiące przed szczytem NATO w Warszawie. Politycy rządzącej partii, a za nimi szef dyplomacji, zdają się zapominać, iż głównym sojusznikiem USA w Europie są Niemcy, a nie Wielka Brytania, czy Francja, a zatem dystansowanie się Warszawy od Berlina osłabia wybitnie miejsce Polski w polityce amerykańskiej w Europie. Ponadto z uwagi na rolę prasy w USA w kształtowaniu opinii administracji na temat problematyki międzynarodowej, zwłaszcza takich mediów jak «New York Times», «Washington Post» czy portal Politico, 
niezrozumiałym wydaje się być zaniedbywanie przez polską dyplomację kreowania pozytywnego wizerunku kraju, a wręcz poprzez publicystyczne, a nawet obraźliwe wypowiedzi w mediach ministra Waszczykowskiego, jego podważanie w oczach opinii międzynarodowej [5, s. 5, 8-9]. Wymowną ilustracją obecnego miejsca Polski na arenie międzynarodowej, pozycji w Unii Europejskiej czy relacji z USA może być spotkanie prezydenta Obamy 25 kwietnia w Hanowerze z przywódcami największych państw europejskich, na które nie zaproszono przedstawiciela Polski.

Wśród nowych wektorów polityki zagranicznej Polski należy wskazać na:

6. Ideę powrotu do koncepcji międzymorza oraz jej konsekwencje dla pozycji międzynarodowej Polski w Europie Środkowej i Wschodniej. Zdaniem rządzącej w Polsce prawicy, idea ta zasługuje na to, by mutatis mutandis stać się jednym z filarów polskiej polityki zagranicznej, komplementarnym względem orientacji na Brukselę (tj. NATO i UE). Koncepcja została szeroko zaprezentowana przez Witolda Waszczykowskiego w maju 2011 r. z ramienia Instytutu Sobieskiego podczas I edycji kongresu «Polska - wielki projekt». Obecny szef MSZ przekonywał zebranych, iż państwa środkowoeuropejskie, mające wspólne interesy i doświadczenia historyczne, winny wspierać się wzajemnie, bo razem stanowią znaczną siłę, np. same dziewięć państw-uczestników spotkania bukareszteńskiego «flanki wschodniej NATO» to prawie 95 mln mieszkańców, czyli 60-65 procent całej ludności Rosji i około 115 procent ludności Niemiec, z niemałymi wszak walorami gospodarczymi. Ponadto - zdaniem Waszczykowskiego - dochodzi do tego Słowenia, Finlandia, być może Mołdawia [3, s. 1-2]. W następstwie wydarzeń, jakie miały miejsce od lata 2008 r., tzn. od próby najazdu rosyjskiego na Gruzję, aneksji Krymu i walk w Donbasie nastąpiło - w ocenie szefa MSZ - otrzeźwienie w całej prawie Europie Środkowej, a więc szanse na urzeczywistnienie projektu międzymorza wydają się znaczne.

Odkładając na bok względy natury ideologicznej, a skupiając się wyłącznie na przesłankach geopolitycznych i geostrategicznych, a nawet doświadczeniach historycznych, wypada uznać koncepcje międzymorza jako anachroniczną, nieuwzględniającą zasadniczych sprzeczności pomiędzy państwami międzymorza, np. w kwestii relacji z Rosją (Węgry zainteresowane stosunkami z Niemcami, Rosją i Turcją - Polska na bardzo odległym planie w polityce węgierskiej; Rumunia i Bułgaria - czy też zagrożonych polityką Kremla państw bałtyckich), Czechy i prezydent Milos Zeman konsekwentnie opowiada się za rozszerzeniem współpracy z Rosja, podobnie jak partia Roberta Fico na Słowacji.

Wydaję się, iż można się pokusić o konstatację, że koncepcja międzymorza, afiliowana przez polityków prawicy i realizowana przez polską dyplomację, jest nawet niezgodna $\mathrm{z}$ polską racją stanu. Operowanie przez jej zwolenników danymi statystycznymi, np. obszar, liczba ludności, potencjał militarny, abstrahuje od realiów współczesnej polityki międzynarodowej i bezpieczeństwa, stawiając projekt europejski w opozycji do idei międzymorza. Tak zarysowana koncepcja polityki zagranicznej Polski w sposób bezpośredni wpływa na i tak już napięte od dawna relacje z Moskwą.

7. Stosunki Polski z Federacją Rosyjską są niewątpliwie najgorsze od 1989 r., i chociaż nie można na konto aktywów polityki zagranicznej Polski zapisać fiaska w 
kwestii stałych baz, na rzecz obecności rotacyjnej sił NATO w Europie Środkowej i Wschodniej, to paradoksalnie konflikt na Ukrainie wzmacniał zainteresowanie NATO regionem. Przejawem nowej strategii stała się zapowiedź administracji amerykańskiej w sprawie obecności brygady pancernej w Europie Środkowej i Wschodniej, a więc zahamowanie procesu redukcji obecności militarnej USA na Starym Kontynencie. Tradycyjnie doniosłe znaczenie dla pozycji międzynarodowej Polski, szczególnie w wymiarze bezpieczeństwa posiadają od czasów restytucji niepodległości Ukrainy stosunki Warszawy z Kijowem.

8. Miejsce Ukrainy w polityce zagranicznej Polski w kontekście konfliktu ukraińsko-rosyjskiego systematycznie ulega osłabieniu poprzez wykluczenie Warszawy z tzw. formatu normandzkiego. Rola Polski w stabilizacji regionu musi być postrzegana poprzez fakt podstawowy, streszczający się w odrzuceniu latem $2015 \mathrm{r}$. przez prezydenta Poroszenkę inicjatywy prezydenta Dudy związanej z poszerzeniem formatu normandzkiego. Kijów nadal uznaje Warszawę za partnera strategicznego, ale woli najważniejsze kwestie rozwiązywać w węższym gronie z udziałem Niemiec i Francji, ale bez Polski.

\section{Wnioski}

- Z uwagi na prymat kwestii wewnętrznych w stosunku do polityki zagranicznej oraz konflikt z Brukselą związany z przestrzeganiem demokracji w Polsce, ośrodek decyzyjny w PiS nie będzie na szerszą skalę angażował się w działania na rzecz wspierania reform na Ukrainie, skupiając się na głośnym artykułowaniu całokształtu problematyki związanej z agresywną polityką Federacji Rosyjskiej wobec Ukrainy (działania militarne, gospodarcze, propagandowe będą krytykowane na forum międzynarodowym przez rząd RP, a więc zagrożenia w stosunku do całego regionu będą definiowane i piętnowane).

- W obliczu słabnącej pozycji Polski w UE będzie malało jej zainteresowanie Ukrainą, ponadto kilkanaście ostatnich miesięcy pokazuje, iż Kijów nie jest zanadto przekonany do koncepcji większego zaangażowania Warszawy w rozwiązanie konfliktu ukraińsko-rosyjskiego i nie dostrzega potrzeby rozszerzenia formatu normandzkiego o inne kraje, w tym Polskę.

- Już w czasie trwania w Polsce koalicji PO-PSL, zwłaszcza w drugiej kadencji (2011-2015), znaczenie Ukrainy w polityce zagranicznej Polski słabło. Dziś Warszawa, zmniejszając temperature relacji z Brukselą, sama $\mathrm{w}$ perspektywie długofalowej (nowa zintegrowana unia wokół Niemiec i Francji) zmierza w stronę szarej strefy, pozycjonując się poza głównym obszarem stosunków międzynarodowych.

- W kontekście polityki zagranicznej polityczna suwerenność Polski w Unii Europejskiej, głoszona w dobie jednowładztwa Jarosława Kaczyńskiego, wydaje się anachroniczna, wywodząca się wprost z XIX wiecznego rozumienia kategorii państwa, narodu, czy suwerenności w szczególności. Dla porównania $\mathrm{z}$ trafną obserwacją Stanisława Bielenia, że dla USA priorytetem demokracji jest wolność, dla demokracji europejskiej równość, to dla Rosji, a - zdaniem Autora - także i Polski, jako główny czynnik składowy demokracji suwerennej - bezpieczeństwo [2, s. 87]. Naturalnie bezpieczeństwo rozumiane inaczej w Moskwie, a inaczej w Warszawie. 
- Dotychczasowy model relacji polsko-ukraińskich dobiega końca, a to oznacza ostateczne w klasycznym rozumieniu pogrzebanie przez Warszawę idei wywodzącej się z kręgu «Paryskiej Kultury» ULB i przejście Polski do realizacji wizji quasimocarstwowości i międzymorza. A zatem koncepcja powrotu do powstałej w innych realiach polityczno-militarnych piłsudczykowskiej idei Międzymorza, anachronicznej $\mathrm{w}$ swojej warstwie historycznej i merytorycznej, niezrealizowanej $\mathrm{z}$ uwagi na nierozwiązywalny węzeł sprzeczności i antagonizmów narodowych oraz rozbieżne ambicje terytorialne państw środkowoeuropejskich doby powersalskiej, została podjęta $\mathrm{w}$ nowej formule jako osobliwe, wręcz kuriozalne wyzwanie dla polskiej dyplomacji po zwycięskich dla obozu prawicy wyborach 2015 r. Centralne miejsce w nowej wersji międzymorza miały zająć państwa - uczestnicy spotkania bukaresztańskiego, naturalnie bez Ukrainy, ale pod przywództwem Polski.

\title{
BIBLIOGRAFIA
}

1. Balcer A. Jaka zmiana. Założenia i perspektywy polityki zagranicznej rządu PiS / A. Balcer, P. Buras, G. Gromadzki, E. Smolar // Fundacja im. Stefana Batorego. - Warszawa, 2016 r. - S. 2.

2. Bieleń St. Panrosjanizm w rosyjskiej tożsamości mocarstwowo-imperialnej / St. Bieleń // Konflikty zbrojne na Ukrainie i Bliskim Wschodzie. Nowe wyzwania dla międzynarodowego bezpieczeństwa ; Bezpieczeństwo i Dyplomacja ; red. M. Mróz. - 2015. - № 1(3). - Wrocław. - S. 87.

3. Brzeznicki A. Dodatek Polityka Bezpieczeństwa Ukrainy i Polski. Unia - Tak, «Międzymorze» - Nie / A. Brzeznicki, A. Smolar // Fundacja im. Stefana Batorego. - Warszawa, 28 września 2015. S. $1-2$.

4. Informacja Ministra Spraw Zagranicznych o zadaniach polskiej polityki zagranicznej w 2016 roku. - www.msz.gov.pl dostęp 23 lutego 2016.

5. Kelemen R. D. Europe's Autocracy Problem. Polish Democracy Final Days? / R. D. Kelemen, M. A. Orenstein // Financial Times. - 7 stycznia 2016. - S. 7.

6. Stosunki międzynarodowe. Geneza, struktura, dynamika / red. E. Haliżak, R. Kuźniar. Warszawa, 2006. - S. 122.

7. Teorie stosunków międzynarodowych / red. S. Burchill, R. Devetak, A. Linklater, M. Paterson, Ch. Reus-Smit, J. True. - Warszawa, 2006.

8. Współczesne stosunki międzynarodowe / red. T. Łoś-Nowak. - Wrocław, 2008. - S. 76.

Стаття надійшла до редколегії 01.09.2016

Прийнята до друку 15.10.2016

\section{НОВІ ВЕКТОРИ ЗОВНІШНЬОЇ ПОЛІТИКИ ПОЛЬЩІ ПІСЛЯ ВИБОРІВ 2015 РОКУ ТА ЇХНІЙ ВПЛИВ НА УКРАЇНСЬКО-ПОЛЬСЬКІ ВІДНОСИНИ}

\author{
Мацей Мруз \\ Інститут Міжнародних Відносин, Вроилавський Університет, \\ вул. Кочарова, 3, м. Врочлав, Польща, 51-149
}

Обіцяні консервативною партією-переможницею зміни в Польщі 2015 року стосуються також зовнішньої політики. Передбачали вони, між іншим, збільшення суб'єктної ролі Польщі в Європейському Союзі, відхід від надмірного підпорядкування порадам, які надходили 3 європейського твердого ядра - Берліна та Парижа, повернення до ідеї міжмор'я та вчинення 3 Великобританії головного партнера Варшави в Європі. Нова зовнішня політика Польщі не залишилася без впливу на рівень двосторонніх відносин з Україною. Існуюча до цього часу модель польсько-українських відносин, які спиралися на так званому стратегічному партнерстві, 
закінчується, а це означає рішучу відмову Варшави від ідеї УЛБ (Україна-Литва-Білорусь) і перехід Польщі до реалізації бачення quasi-наддержавності і міжмор'я з участю держав-учасниць бухарестської зустрічі, отож без України. 3 іншого боку, перед послабленням позиції Польщі в ЄС, зменшуватиметься її зацікавленість Україною. Окрім того, понадрічний відрізок часу ілюструє, що Київ не надто переконаний у концепції більшого заангажування Варшави у вирішенні російськоукраїнського конфлікту та не помічає потреби розширення нормандського формату на інші країни, у тім числі Польщу.

Ключові слова: Польща; Україна; Європейський Союз; НАТО; Сполучені Штати Америки; Російська Федерація; Міжмор'я.

\title{
NEW VECTORS POLISH FOREIGN POLICY AFTER ELECTION 2015 AND THEIR IMPACT ON UKRAINIAN-POLISH RELATIONS
}

\author{
Maciej Mróz \\ Institute of International Studies, University of Wroctaw, \\ 3, Koszarowa Str., Wrocław, Poland, $51-149$
}

Changes propounded by the winning right-wing camp in Poland have also comprised foreign policy.

They postulated, inter alia, increase in Poland's role as an actor of the European Union, ceasing of being unduly succumbed to suggestions coming from the hard core of the EU - Berlin and Paris, return to the idea of Intermarium and making Great Britain Warsaw's leading partner in Europe. The new foreign policy of Poland has affected the level of bilateral relations with Ukraine. The previous model of the Polish-Ukrainian relations, based on the so called strategic partnership, is coming to an end, which implies that Warsaw will definitively abandon the ULB idea. Instead, Poland will start pursuing the concept of quasi-powerdom and Intermarium, involving the participant states of the Bucharest meeting, and thus without Ukraine. On the other hand, given the weakening position of Poland in the EU, its interest in Ukraine will be diminishing. Furthermore, the events of the recent months show that Kiev is not overly convinced about the concept on Warsaw's intense engagement in the Ukrainian-Russian conflict settlement and does not see the need for expanding the Norman format with other countries, including Poland.

Key words: Poland; Ukraine; European Union; NATO; United States; Russian Federation; Intermarium. 